\title{
REMOTE SENSING AS AN INDIRECT WAY TO ESTIMATE BIOPHYSICAL AND BIOCHEMICAL PROPERTIES OF BEANS CROP
}

\author{
Adel H. Elmetwalli*
}

\begin{abstract}
Non-destructive monitoring of agricultural crops becomes more important to improve crop productivity. In site specific management, insitu remotely sensed data is of significant importance for quantifying nitrogen deficiency and salinity stress effects on crops. In the reported research, the visible and near infrared portions of the electromagnetic spectrum were used to derive vegetation indices sensitive to nitrogen deficiency and salinity stress in beans (Phaseolus Vulgaris, L). Four nitrogen fertilization rates $(0,30,60$ and $100 \mathrm{~kg} / \mathrm{ha})$ and three water salinity levels $(1.5,3$ and $5 \mathrm{dS} / \mathrm{m})$ were used to subject plants to both stressors. Reflectance measurements were collected from beans plants under artificial illumination conditions at different growth stages and used to calculate 45 commonly used vegetation indices for predicting beans properties. Strong significant correlations between beans properties and different vegetation indices were observed. $C_{\text {rededge }}$ and $R_{750} / R_{700}$ ratio were found to be the optimum indices for predicting beans chlorophyll content $(r=0.657)$. $R_{710} / R_{760}$ ratio was also found to be the optimum index for predicting beans biomass $(r=-0.582)$. PSNDb was found to be sensitive to beans grain yield ( $r>0.595)$. The correlations with grain yield were found to be strongest at the R6 growth stage.
\end{abstract}

Keywords: beans, remote, sensing, nitrogen, salinity, reflectance

\section{INTRODUCTION}

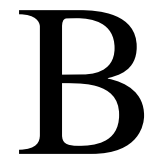
eans seeds (Phaseolus vulgaris, L.) are grown over a wide range of climatic conditions and soil types. It is one of the important foods worldwide since it is a rich source of protein and also is consumed as a vegetable crop when grown for its immature pods. These immature pods are rich in protein and iron and contain basic nutrients for health including ascorbic acid, vitamin A and B, and calcium (Ndegwa et al., 2006).

\footnotetext{
*Assi. Prof., Agric. Eng. Dept., Fac. of Agric., Tanta Univ., Egypt.
} 
Many areas in arid and semi-arid regions suffer from the scarcity of fresh water and resultantly agricultural saline water becomes an important alternative water resource in agricultural irrigation (Bao and $\mathrm{Li}, 2010$ ). As a result of the rapid population growth worldwide, as much as $60 \%$ of the world's population may face the danger of water scarcity by the year 2025 (Qadir et al., 2007). It is therefore very important to use limited water resources more efficiently. In agriculture, many ways have been employed to use available water resources more efficiently. For example, the development of deficit irrigation could be a better way of water saving (Kirda et al., 2004). Modern irrigation systems are also a good alternative to traditional flood irrigation. With regard to the improvements of water saving these techniques are not enough to sustain population demands and therefore many countries worldwide have policies to use low water quality (Bao and $\mathrm{Li}, 2010$ ). Other modern technologies are fundamentally required to detect stress in crops at early stages and thus avoid crop reductions. In this context, remotely sensed data may be a reliable technique for this purpose. Monitoring beans from being affected by different sources of stress is important to avoid crop reductions and resultantly maximize productivity. Crop production is highly constrained by nitrogen deficiency as nitrogen is considered the most intensively managed plant nutrient in crop production (Schlemmer et al., 2005).

Traditional methods of identifying crop status in terms of stress are time consuming, laborious and costly. Alternatively, non-destructive techniques (e.g. remote sensing) can be a quick and robust way to assess plant health status. Remotely sensed data can show variations in plants before they can be seen visually. The most commonly used vegetation indices are broad band indices in the VIS and NIR (Monteiro et al., 2012). Normalized Difference Vegetation Index is one of the most commonly used vegetation indices and many studies related this index to various crop properties (Eitel et al., 2008; Galvao et al., 2009). 
Previous studies based their research on hyperspectral vegetation indices documented the effectiveness of narrow band indices in assessing crop water or nitrogen status for precision farming practices (Stagakis et al., 2010). Hyperspectral reflectance data have the possibility of showing much more variations on vegetation than narrow band data (Thenkabail et al., 2000). Narrow band spectral data have low capability of distinguishing sources of stress while hyperspectral data give a step forward to the accurate distinguishing of different sources of stress. Elmetwalli et al. (2012) documented the effectiveness of hyperspectral data to distinguish sources of stress.

However most of the published work focused on the detecting and distinguishing stress resulted from nitrogen or moisture very little attention has given to the detection and distinguishing nitrogen deficiency from salinity stress and thus the overall aim of the reported research is to assess the effectiveness of in situ hyperspectral measurements for the detection and distinguishing nitrogen and salinity spectrally in beans. This research aimed to (i) investigate the influence of salinity and nitrogen deficiency stress on beans crop and the resulting spectral reflectance characteristics at the leaf and canopy scale (ii) assess the effectiveness of different vegetation indices to predict crop biophysical and biochemical properties and (iii) assess the possibility to distinguish salinity from nitrogen deficiency spectrally.

\section{MATERIALS AND METHODS}

The experimental work was undertaken in a controlled greenhouse at the University of Stirling, Stirling, United Kingdom (latitude of 56.15 and longitude of 3.92) in 2013 spring season. The soil used was brought from the state gardens of the university. To ensure soil homogeneity, the soil was mixed thoroughly before being transferred to the pots and some samples were taken for chemical and physical analysis. Seeds were sown on $24^{\text {th }}$ March 2013 at a temperature and relative humidity of $20{ }^{\circ} \mathrm{C}$ and $60 \%$ respectively. Four levels of nitrogen fertilization of $0,30,60$, and $100 \mathrm{~kg} / \mathrm{ha}$ and three levels of water salinity of $1.5,3$ and $5 \mathrm{dS} / \mathrm{m}$ were 
used to subject plants to a range of nitrogen deficiency and salinity stresses. Different levels of saline solutions were made up using both sodium and calcium chloride with a ratio of 1:1. Nitrogen fertilization in the form of ammonium nitrate was applied as recommended in two equal doses. The first was applied three weeks after planting and the second at 45 days after planting. To ensure high germination percentage, three seeds were sown in each pot and later thinned to two plants a week after plant emergence. Following the spectroradiometery measurements, plant samples were collected for identifying crop biophysical and biochemical properties including yield, biomass, and chlorophyll content. Leaf discs were collected from apical leaves using a $10 \mathrm{~mm}$ diameter leaf corer for the determination of chlorophyll content that was determined according to Lichtenthaler (1987) using the following Equation:

$$
\text { Chl } a=12.21 \mathrm{~A}_{663}-2.81 \mathrm{~A}_{646}
$$

Where: Chl $a$ is the chlorophyll $a$ content in $\mu \mathrm{g} \mathrm{cm}^{-3}$ of the $90 \%$ acetone solution, $A_{646}$ and $A_{663}$ are the absorbance at 646 and $663 \mathrm{~nm}$ wavelengths respectively. At the end of the growing season, when all leaves turned to dry and yellow colour, the pods were collected and threshed manually to identify crop yield.

\section{Spectra collection and analysis}

Spectra measurements were collected at different growth stages in a designed darkroom with controlled illumination conditions using an ASD FieldSpec Pro spectroradiometer (Analytical Spectral Devices, Boulder, Co, USA). To avoid variation in light intensity a darkroom was set up with the dimensions $2 * 2 * 2.8 \mathrm{~m}$ (width*length*height). To eliminate the reflectance from walls, a non-reflective black cloth (reflectance $<5$ ) was installed on all sides of the room. A tripod was fixed on the ceiling of the room holding two 300 watt halogen lamps and the sensor. The spectroradiometer with a foroptic of $3.5^{\circ}$ field of view was fixed at $1 \mathrm{~m}$ from pots surface. It has also $300-1100 \mathrm{~nm}$ spectral range covering the VIS and NIR parts of the spectrum with a sample interval of $3 \mathrm{~nm}$. A white reference panel measurement was collected before each spectrum. 
Three replications of each treatment were chosen randomly for the collection of spectra measurements. 10 spectra for each pot were acquired to reduce variations within each pot. The collected spectra were used to calculate 45 different broadband and hyperspectral vegetation indices (calculations of these indices are detailed in Elmetwalli, 2008). Examples of these indices are;

$$
\operatorname{PSND}_{b}=\frac{R_{800}-R_{635}}{R_{800}+R_{635}} ; \text { Crededge }=\frac{R_{800}}{R_{700}}-1
$$

\section{Statistical analysis}

Minitab v15 was used to perform one and two way analysis of variance (ANOVA) to establish significant differences in beans crop responses under nitrogen deficiency and salinity stresses. Data were checked for normality using Anderson-Darling method with a 95\% significance level. The Pearson Product Moment correlation coefficient was used to test the association between different vegetation indices and crop properties and to identify optimum vegetation indices for predicting beans properties.

\section{RESULTS}

\section{Effects of salinity and nitrogen fertilization on beans grain yield}

ANOVA analysis was performed to investigate the effects of both salinity and nitrogen fertilization rates on biophysical and biochemical properties of beans. The results showed that both salinity and nitrogen fertilization significantly affected beans grain yield. Nitrogen fertilization strongly reduced beans grain yield $\left(\mathrm{R}^{2}=0.88\right.$ and $\left.\mathrm{p}<0.005\right)$. The highest beans grain yield of $2.91 \mathrm{Mg} / \mathrm{ha}$ was recorded with the treatment received fresh water and $100 \mathrm{~kg} \mathrm{~N}$ whilst the lowest beans grain yield of 1.43 $\mathrm{Mg} / \mathrm{ha}$ was recorded with the treatment received $0 \mathrm{~kg} \mathrm{~N}$ and $5 \mathrm{dS} / \mathrm{m}$ salinity.

Salinity also significantly affected beans grain yield measured in different treatments $\left(\mathrm{R}^{2}=0.79\right)$. Significant decreases in beans grain yield were observed with increasing water salinity levels. The grain yield fell to about $50 \%$ of the maximum value when subjected to the highest water salinity and zero nitrogen fertilization. This indicates that 
yield reductions were highest in treatments with the lowest nitrogen fertilization rate and highest water salinity. The results therefore demonstrated large variations in beans yield which mainly attributed to different nitrogen and water salinity treatments. Aboveground biomass was also affected by both salinity and nitrogen deficiency which highly correlates with final grain yield.

\section{Association between beans biophysical properties and vegetation indices}

A total of 45 broad band and hyperspectral vegetation indices were calculated and evaluated to predict beans different biophysical and biochemical properties. At early growth stages the majority of vegetation indices used demonstrated non significant correlations with beans grain yield. The spectra data collected at different growth stages were averaged and ranked and then used to identify the optimum index for predicting beans grain yield. The ranking results showing the top 15 vegetation indices to predict beans grain yield are summarised in Table 4 .

At the $V_{2}$ and $V_{3}$ growth stages (first and third trifoliolate leaf unfolded), the coefficient of correlation was not significant for the majority of indices. At the $\mathrm{V}_{4}$ stage, most vegetation indices demonstrated significant correlations with the measured beans grain yield. The coefficient of correlation increased gradually to reach a maximum at the $\mathrm{R}_{6}$ growth stage (first flowers developed) at both the leaf and canopy scales. The PSND $_{b}$ was identified as the optimum index to predict beans grain yield since it gives the highest mean value of the correlation coefficient throughout the growing season $(\mathrm{R}=0.595)$. Other indices such as RDVI, $\mathrm{R}_{710} / \mathrm{R}_{760}$ and $\mathrm{R}_{750} / \mathrm{R}_{700}$ also produced strong significant correlations with the measured grain yield. Figure 1 shows the relationship between PSNDb and beans grain yield at the $\mathrm{R}_{6}$ stage $\left(\mathrm{R}^{2}=0.578\right.$; $\left.\mathrm{p}<0.005\right)$. Same trend was observed with biomass since the results showed no significant correlations with different indices at $\mathrm{V} 1$ and $\mathrm{V}_{3}$. The highest correlations were observed at the $\mathrm{R}_{6}$ stage. The highest mean value of correlation coefficient was recorded with $\mathrm{R}_{710} / \mathrm{R}_{760}$ ratio (Table 1 ). 
Table 1 Coefficient of correlation for the relationship between different vegetation indices and both yield and aboveground biomass of beans crop at different growth stages

\begin{tabular}{|c|c|c|c|c|c|c|c|c|c|}
\hline \multirow{2}{*}{$\begin{array}{l}\text { Crop } \\
\text { property }\end{array}$} & \multirow{2}{*}{ VI } & \multicolumn{7}{|c|}{ Growth stage } & \multirow{2}{*}{ Mean } \\
\hline & & V2 & V3 & V4 & R6 & R8 & $\mathrm{R} 9 \mathrm{a}$ & $\mathrm{R} 9 \mathrm{~b}$ & \\
\hline \multirow{16}{*}{ Yield } & NDVI & 0.200 & 0.413 & 0.615 & 0.746 & 0.733 & 0.708 & 0.625 & 0.577 \\
\hline & RVI & 0.163 & 0.396 & 0.678 & 0.760 & 0.769 & 0.704 & 0.645 & 0.588 \\
\hline & $\mathrm{GNDVI}_{\mathrm{br}}$ & 0.206 & 0.321 & 0.670 & 0.762 & 0.761 & 0.676 & 0.745 & 0.592 \\
\hline & GNDVI $_{\text {hy }}$ & 0.207 & 0.304 & 0.672 & 0.752 & 0.747 & 0.671 & 0.747 & 0.586 \\
\hline & $\mathrm{PSND}_{\mathrm{b}}$ & 0.202 & 0.392 & 0.646 & 0.767 & 0.761 & 0.708 & 0.687 & $\underline{0.595}$ \\
\hline & $\mathrm{R}_{800} / \mathrm{R}_{550}$ & 0.202 & 0.289 & 0.717 & 0.725 & 0.691 & 0.639 & 0.731 & 0.571 \\
\hline & $\mathrm{R}_{695} / \mathrm{R}_{760}$ & -0.203 & -0.338 & -0.634 & -0.774 & -0.739 & -0.715 & -0.696 & -0.585 \\
\hline & $\mathrm{R}_{605} / \mathrm{R}_{760}$ & -0.205 & -0.373 & -0.641 & -0.753 & -0.751 & -0.704 & -0.709 & -0.591 \\
\hline & $\mathrm{R}_{710} / \mathrm{R}_{760}$ & -0.206 & -0.306 & -0.658 & -0.778 & -0.768 & -0.689 & -0.752 & -0.594 \\
\hline & $\mathrm{R}_{750} / \mathrm{R}_{700}$ & 0.191 & 0.304 & 0.722 & 0.755 & 0.742 & 0.669 & 0.763 & 0.592 \\
\hline & $R_{780}-R_{710}$ & \multirow[b]{2}{*}{0.166} & \multirow[b]{2}{*}{0.290} & \multirow[b]{2}{*}{0.651} & \multirow[b]{2}{*}{0.713} & \multirow[b]{2}{*}{0.765} & \multirow[b]{2}{*}{0.646} & \multirow[b]{2}{*}{0.762} & \multirow[b]{2}{*}{0.570} \\
\hline & $R_{780}-R_{680}$ & & & & & & & & \\
\hline & RDVI & 0.180 & 0.402 & 0.663 & 0.767 & 0.771 & 0.712 & 0.646 & 0.592 \\
\hline & IPVI & 0.200 & 0.413 & 0.615 & 0.746 & 0.733 & 0.708 & 0.625 & 0.577 \\
\hline & Cgreen & 0.202 & 0.289 & 0.717 & 0.725 & 0.691 & 0.639 & 0.731 & 0.571 \\
\hline & Crededge & 0.192 & 0.300 & 0.721 & 0.754 & 0.740 & 0.662 & 0.759 & 0.590 \\
\hline \multirow{15}{*}{ Biomass } & NDVI & 0.188 & 0.280 & 0.583 & 0.718 & 0.701 & 0.674 & 0.682 & 0.546 \\
\hline & SAVI & 0.206 & 0.340 & 0.593 & 0.681 & 0.707 & 0.616 & 0.685 & 0.547 \\
\hline & GNDVI $_{\mathrm{br}}$ & 0.177 & 0.300 & 0.713 & 0.781 & 0.695 & 0.574 & 0.722 & 0.561 \\
\hline & GNDVI $_{\text {hy }}$ & 0.184 & 0.290 & 0.734 & 0.784 & 0.635 & 0.574 & 0.727 & 0.561 \\
\hline & $\mathrm{R}_{800} / \mathrm{R}_{550}$ & 0.193 & 0.270 & 0.738 & 0.812 & 0.619 & 0.555 & 0.731 & 0.560 \\
\hline & $\mathrm{R}_{695} / \mathrm{R}_{760}$ & -0.196 & -0.296 & -0.615 & -0.730 & -0.726 & -0.632 & -0.715 & -0.559 \\
\hline & $\mathrm{R}_{605} / \mathrm{R}_{760}$ & -0.184 & -0.284 & -0.640 & -0.754 & -0.686 & -0.622 & -0.698 & -0.552 \\
\hline & $\mathrm{R}_{710} / \mathrm{R}_{760}$ & -0.233 & -0.333 & -0.703 & -0.742 & -0.724 & -0.592 & -0.746 & $\underline{-0.582}$ \\
\hline & $\mathrm{R}_{750} / \mathrm{R}_{550}$ & 0.191 & 0.310 & 0.742 & 0.814 & 0.625 & 0.567 & 0.733 & 0.569 \\
\hline & $\mathrm{R}_{750} / \mathrm{R}_{700}$ & 0.180 & 0.260 & 0.730 & 0.784 & 0.700 & 0.573 & 0.733 & 0.566 \\
\hline & $\frac{R_{780}-R_{710}}{R_{780}-R_{680}}$ & 0.220 & 0.300 & 0.734 & 0.511 & 0.714 & 0.703 & 0.683 & 0.552 \\
\hline & OSAVI & 0.201 & 0.331 & 0.595 & 0.717 & 0.705 & 0.649 & 0.683 & 0.555 \\
\hline & RDVI & 0.154 & 0.274 & 0.623 & 0.751 & 0.720 & 0.647 & 0.701 & 0.553 \\
\hline & Cgreen & 0.193 & 0.333 & 0.738 & 0.812 & 0.619 & 0.555 & 0.731 & 0.569 \\
\hline & Crededge & 0.182 & 0.302 & 0.730 & 0.783 & 0.697 & 0.566 & 0.732 & 0.570 \\
\hline
\end{tabular}




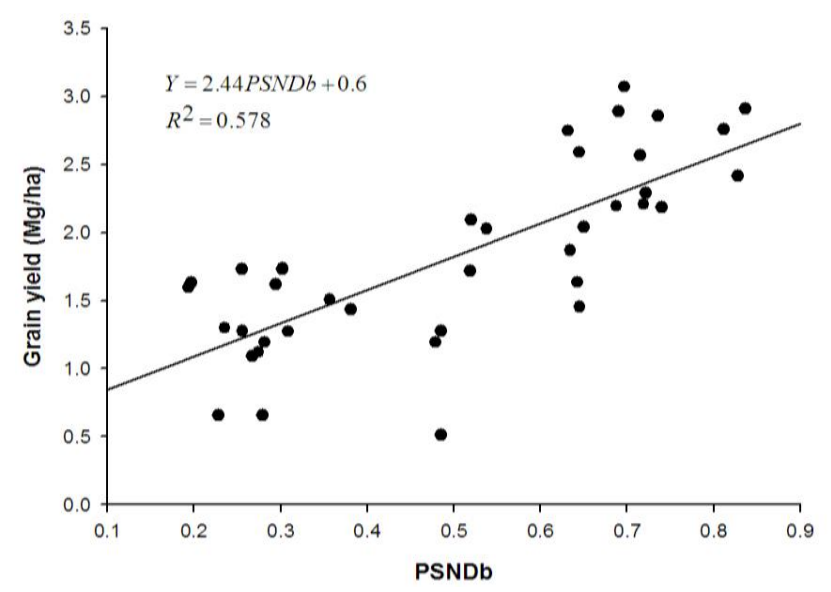

Fig. 1 The relationship between PSNDb derived from hyperspectral spectroradiometry measurements obtained using artificial illumination and beans grain yield at the R6 growth stage.

\section{Association between beans chlorophyll content and vegetation indices}

Different derived vegetation indices were related to chlorophyll content of beans at different growth stages. Table 2 details the relationship between chlorophyll content and various vegetation indices. The results showed no significant correlations between the tested vegetation indices and chlorophyll content at early growth stages $\left(\mathrm{V}_{2}\right.$ and $\left.\mathrm{V}_{3}\right)$ since the chlorophyll concentration was roughly the same in all treatments. From stage V4 onwards, the majority of tested indices produced significant correlations reaching the maximum at R6 growth stage.

The results further showed that hyperspectral have advantages over broad band vegetation indices. Just RVI and GNDVI $\mathrm{br}_{\mathrm{b}}$ as broadband indices are among the top 15 indices for predicting chlorophyll content of beans whilst 13 hyperspectral indices are ranked among the top 15 indices. The $\mathrm{C}_{\text {rededge }}$ and $\mathrm{R}_{750} / \mathrm{R}_{700}$ ratio were identified as the optimum indices to predict beans chlorophyll content as they produced the highest mean value of correlation coefficient over the growing season $(r=0.657)$. Cgreen, $\mathrm{R}_{750} / \mathrm{R}_{500}$ and $\mathrm{R}_{800} / \mathrm{R}_{550}$ also produced strong significant correlations with the measured grain yield. Figure 2 shows the relationship between $\mathrm{C}_{\text {rededge }}$ and chlorophyll content of beans at the $\mathrm{R}_{6}$ $\left(\mathrm{R}^{2}=0.86 ; \mathrm{p}<0.005\right)$. 
Table 2 Coefficient of correlation for the relationship between different vegetation indices and chlorophyll content of beans crop at different growth stages

\begin{tabular}{|c|c|c|c|c|c|c|c|c|}
\hline \multirow{2}{*}{$\begin{array}{l}\text { Vegetation } \\
\text { index }\end{array}$} & \multicolumn{7}{|c|}{ Growth stage } & \multirow{2}{*}{ Mean } \\
\hline & V2 & V3 & V4 & R6 & R8 & R9a & R9b & \\
\hline RVI & -0.149 & 0.160 & 0.758 & 0.896 & 0.897 & 0.847 & 0.807 & 02 \\
\hline $\mathrm{GNDVI}_{\mathrm{br}}$ & -0.090 & 0.193 & 0.855 & 0.886 & 0.858 & 0.883 & 0.915 & 0.643 \\
\hline GNDVI $_{\text {hy }}$ & -0.071 & 0.200 & 0.863 & 0.886 & 0.857 & 0.889 & 0.926 & 0.650 \\
\hline PSSRb & 0.103 & 0.080 & 0.800 & 0.814 & 0.891 & 0.666 & 0.729 & 0.583 \\
\hline PSND $_{b}$ & -0.115 & 0.168 & 0.813 & 0.843 & 0.871 & 0.841 & 0.829 & 0.607 \\
\hline $\mathrm{R}_{800}-\mathrm{R}_{550}$ & 0.124 & 0.106 & 0.856 & 0.859 & 0.885 & 0.798 & 0.824 & 0.636 \\
\hline $\mathrm{R}_{800} / \mathrm{R}_{550}$ & -0.084 & 0.203 & 0.907 & 0.902 & 0.850 & 0.883 & 0.916 & 0.654 \\
\hline $\mathrm{R}_{710} / \mathrm{R}_{760}$ & 0.067 & -0.195 & -0.860 & -0.891 & -0.853 & -0.888 & -0.891 & - \\
\hline $\mathrm{R}_{750} / \mathrm{R}_{550}$ & -0.085 & 0.202 & 0.907 & 0.905 & 0.859 & 0.886 & 0.924 & 0.645 \\
\hline $\mathrm{R}_{750} / \mathrm{R}_{700}$ & -0.092 & 0.199 & 0.910 & 0.928 & 0.862 & 0.882 & 0.910 & $\underline{0.657}$ \\
\hline$\frac{R_{850}-R_{710}}{R_{850}-R_{680}}$ & 0.094 & 0.199 & 0.861 & 0.895 & 0.774 & 0.884 & 0.875 & 0.655 \\
\hline$\frac{R_{780}-R_{710}}{R_{780}-R_{680}}$ & 0.078 & 0.201 & 0.861 & 0.897 & 0.803 & 0.886 & 0.870 & 0.656 \\
\hline Cgreen & -0.084 & 0.203 & 0.907 & 0.902 & 0.850 & 0.883 & 0.916 & 0.654 \\
\hline Cred edge & -0.091 & 0.199 & 0.910 & 0.928 & 0.857 & 0.879 & 0.916 & $\underline{0.657}$ \\
\hline $\mathrm{C}_{\mathrm{NIR}}$ & -0.040 & 0.201 & 0.887 & 0.903 & 0.681 & 0.879 & 0.810 & 0.617 \\
\hline
\end{tabular}

$\mathrm{V}_{2}$, plants with one leaf; $\mathrm{V}_{3}$,first trifoliolate leaf unfolded; third trifoliolate leaf unfolded; R6 first flowers developed; $\mathrm{R}_{8}$ pods with fully developed seeds; $\mathrm{R}_{9 \mathrm{a}} 50 \%$ of pods changed colors; $\mathrm{R}_{9 \mathrm{a}} 80 \%$ of pods changed colors and leaves start falling

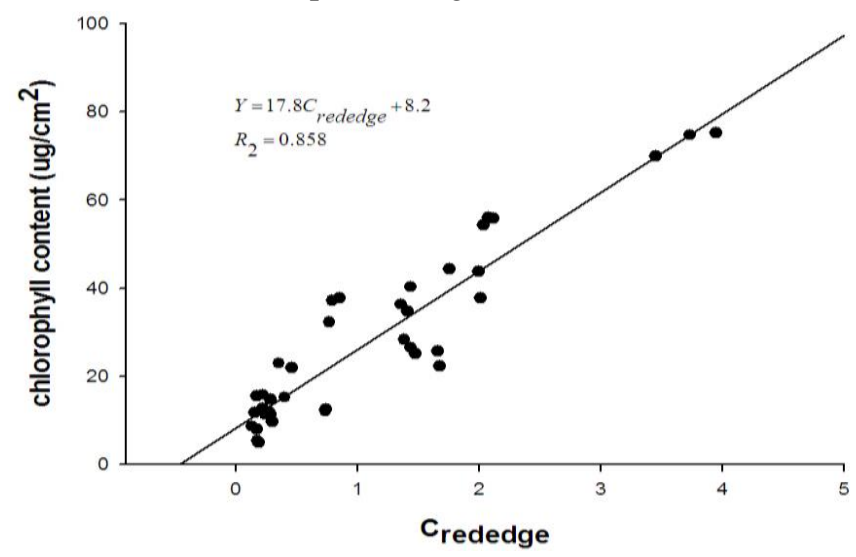

Fig. 2 The relationship between $\mathrm{C}_{\text {rededge }}$ derived from hyperspectral sectroradiometry measurements obtained using artificial illumination and beans grain yield at the $\mathrm{R}_{6}$ growth stage. 


\section{Distinguishing nitrogen deficiency from salinity stress spectrally}

The spectra collected over the growing season was plotted to identify the optimum stage to distinguish sources of stress. Figure 3 depicts the relationship between reflectance and wavelength of the spectra collected from control, high nitrogen deficiency and high salinity stressed treatments. It is obvious that salinity greatly affects the spectral signature especially in the green and red region of the electromagnetic spectrum. Broadly, reflectance increases in the visible part of the spctrum with a greater increase in the red region. The figure shows that salinity stress had a greater effect on the spectral signature of beans in comparison to nitrogen deficiency. This may have been a result of the toxic effect of salinity on the concentration of various pigments particularly chlorophyll.

The results further showed that reflectance values at 555 and $675 \mathrm{~nm}$ wavelengths are sensitive to salinity and nitrogen deficiency stresses. In general, increasing salinity and nitrogen deficiency stress caused an increase in reflectance in the green and red parts of the electromagnetic and no significant increase in reflectance in the near infrared (NIR).
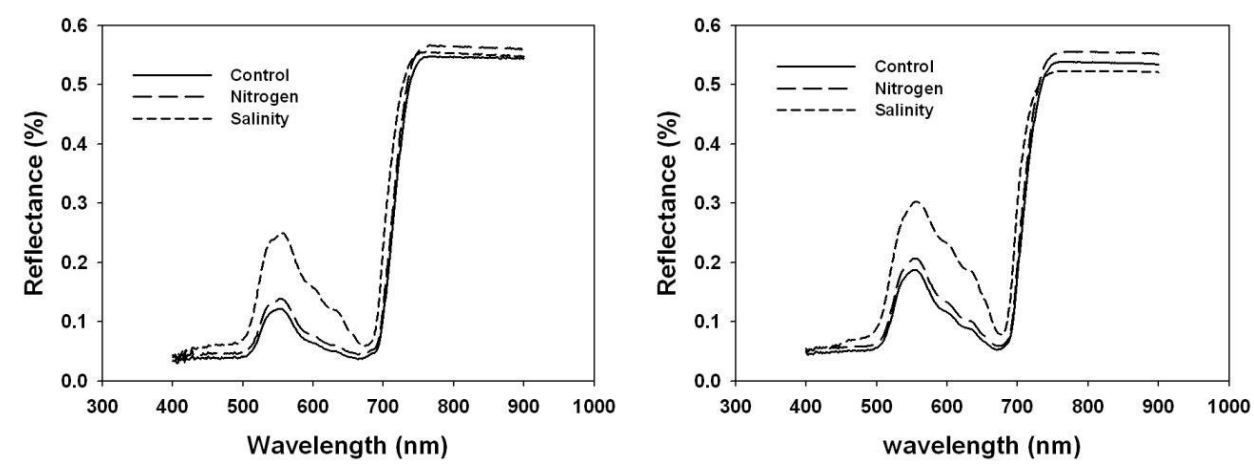

Fig. 3 examples of spectral signature collected from healthy and stressed beans canopies at the $\mathrm{R}_{6}$ and $\mathrm{R}_{8}$ stages using artificial illumination.

\section{DISCUSSION AND CONCLUSION}

Assessing crop productivity in agricultural crops is considered a priority for agricultural research programmes (Steinmetz et al., 1990) in response to the demands of rapid population growth (Rudorff et al., 1996). 
Increased efforts are therefore needed to detect the effects of nitrogen deficiency and salinity stress in agricultural crops. The potential of remote sensing to monitor crop health status has been demonstrated, but published work has focused on detecting moisture and nitrogen deficiency stress (e.g. Xavier et al., 2006; Monteiro et al., 2012). In this study the potential of remote sensing to detect salinity and nitrogen deficiency stress is investigated. Measurements at the canopy scale are arguably important for evaluating the potential successful implementation of satellite remote sensing in precision agriculture.

The reported research assessed the potential of in situ hyperspectral remotely sensed data for predicting beans biophysical and biochemical properties in response to salinity and nitrogen deficiency stress. The spectra measurements were collected at both the leaf and the canopy scales. Our results showed advantage in using hyperspectral indices over broad band vegetation indices. At early growth stages $\left(V_{2}\right.$ and $\left.V_{3}\right)$ the results showed non-significant correlations between vegetation indices and beans properties including yield, biomass and chlorophyll content. Ranking results showed that the optimum index to detect beans grain yield was PSNDb. $\mathrm{C}_{\text {rededge }}$ was shown to be the optimum index to correlate with chlorophyll content of beans $(\mathrm{R}=0.657)$. Hyperspectral indices were shown to be sensitive indicators for predicting beans grain yield, chlorophyll content and biomass since they produced the best indices to correlate with beans properties.

In conclusion, hyperspectral satellite based remote sensing platforms such as Hyperion or Venus with high spectral resolution capabilities would be well suited to predict crops yield in semi arid and arid areas.

\section{REFERENCES}

Bao, H. and Li, Yinxin (2010). Effect of stage-specific saline irrigation on greenhouse tomato production. Irrigation science, 28: 421-430.

Eitel, J. U. H.; Long, D.S.; Gessler, P.E. and Hunt, E.R. (2008). Combined spectral index to improve ground based estimates of nitrogen status in dryland wheat. Agronomy J., 100: 1694-1702.

Elmetwalli, A.H. (2008). Remote sensing as a precision farming tool in the Nile Valley, Egypt. 
Elmetwalli, A.H. Tyler, A.N., Hunter, P.D. and Salt, C.A. (2012). Detecting and distinguishing moisture and salinity induced stress in wheat and maize through in situ spectroradiometery measurements. Remote sensing Letters, 3(5): 363-372.

Galvao, L.S.; Roberts, D.A.; Formaggio, A.R.; Numata, I. and Breuing, F.M. (2009). View angle effects on the discrimination of soybean varieties and on the relationship between the vegetation indices and yield using off nadir hyperion data. Remote Sensing of Environment, 113: 846-856.

Kirda, C.; Cetin, M.; Dasgan, Y.; Topcu, S.; Kaman, H.; Ekici, B.; Derici, M.I. and Ozguven, A.I. (2004). Yield response of greenhouse grown tomato to partial root drying and conventional deficit irrigation. Agricultural Water Management, 69: 191-201.

Lichtenthaler, H. K. (1987). Chlorophylls and carotenoids: Pigments of photosynthetic biomembranes. Methods in Enzymology 148: 349382.

Monteiro, P. F. C.; Filho, R. A.; Xavier, A. C. and Monteiro, R. O. C. (2012). Assessing biophysical variable parameters of bean crop with hyperspectral measurements. Scientia Agricola, 69(2): 87-94.

Ndegwa, A. M.; Muchui, M. N.; Wachiuri, S. M. and Kimamira, J. N. (2006). Evaluation of snap bean varieties for adaptability and pod quality. In: Proceeding of the $10^{\text {th }}$ KARI Biennial Conferenec. KARI HQs, Nairobi, Kenya. $13^{\text {th }}-17^{\text {th }}$ Nov., 2006.

Qadir, M.; Sharma, B.R.; Bruggeman, A.; Choukr-Allah, R. and Karajeh, F. (2007). Non-conventional water resources and opportunities for water augmentation to achieve water security in water scarce countries. Agricultural water management, 87: 2-22.

Rudorff, B. F. T., Mulchi, C. L., Daughtry, C. S. T. and Lee, E. H. (1996). Growth, radiation use efficiency, and canopy reflectance of wheat and corn grown under elevated ozone and carbon dioxide atmospheres. Remote sensing of Environment 55: 163-173.

Schlemmer, M.R., Francis, D.D., Shanahan, J.F. and Schepers, J.S. (2005). Remotely measuring chlorophyll content in corn leaves 
with different nitrogen levels and relative water content. Agronomy Journal, 97: 106-112.

Stagakis, S.; Markos, N.; Sykioti, O. and Kyparissis, A. (2010). Monitoring canopy biophysical and biochemical parameters in ecosystem scale using satellite hyperspectral imagery: an application on a phlomis fruticosa Mediterranean ecosystem using multi angular CHRIS/PROBA observations. Remote Sensing of Environment, 114: 977-994.

Steinmetz, S., Guerif, M., Delecolle, R. and Baret, F. (1990). Spectral estimates of the absorbed photosynthetically active radiation and light-use efficiency of a winter wheat crop subjected to $\mathrm{N}$ and water deficiencies. International Journal of Remote Sensing 11: 1797-1808.

Thenkabail, P.S.; Smith, R.B. and Pauw, E. (2000). Hyperspectral vegetation indices and their relationships with agricultural crops characteristics. Remote Sensing of Environment, 71: 158-182.

Xavier, A.C.; Rundorff, B.F.T.; Moreira, M.A.; Alvarenga, B.S.; Freitas, J.G. and Salmon, M.V. (2006). Hyperspectral field reflectance measurements to estimate wheat grain yield and plant height. Sci. Agric. (Piracicaba, Braz.), 63(2): 130-138.

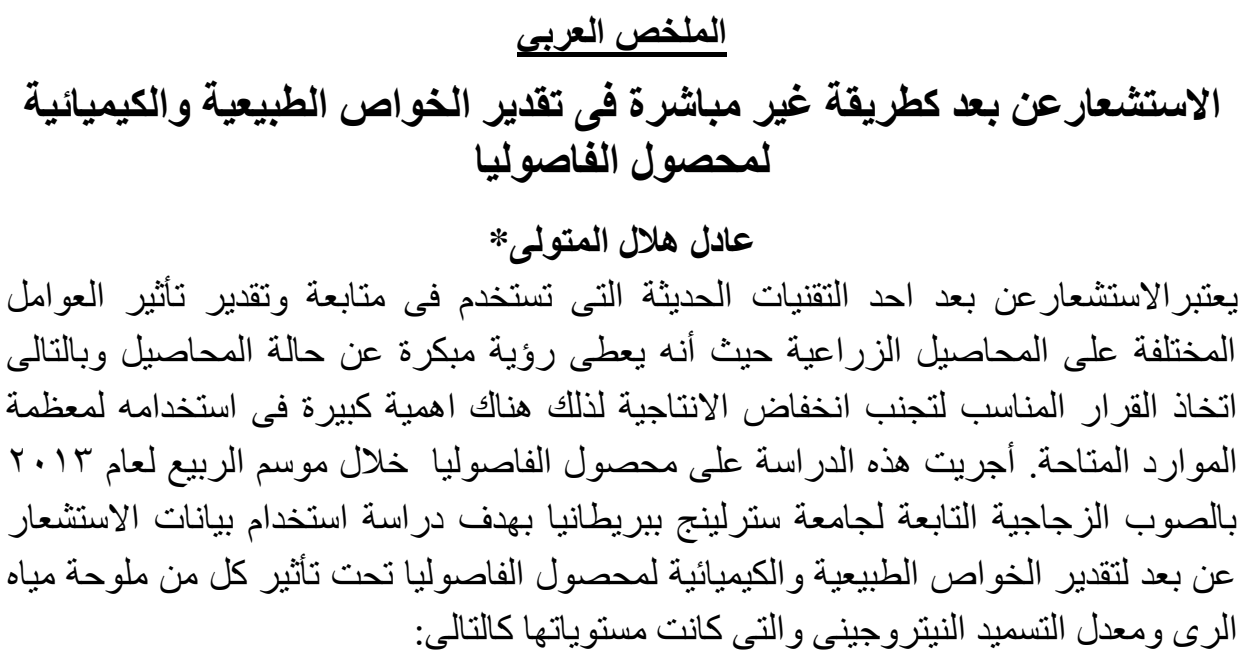

*مدرس الهندسة الزراعية ـ قسم الهندسة الزراعية ـ كلية الزراعة - جامعة طنطا مصر 


$$
\begin{aligned}
& \text { ملوحة مياه الرى 0, 1 ـ ب ـ م ديسيسمنز / م } \\
& \text { ومعدل التسميد النيتروجينى صفر - } 30 \text { - } 60 \text { - . - 1 كجم/هكتار }
\end{aligned}
$$

تم تجميع قياسـات الانعكاس من اسطح النبات عند مر احل النمو المختلفـة وتمت در اسـة العلاقة

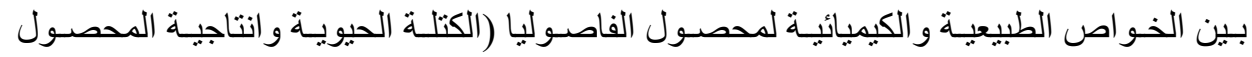

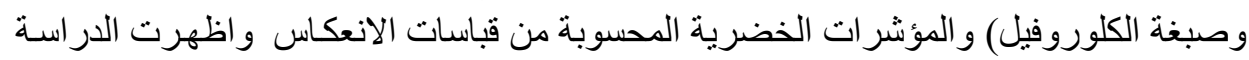

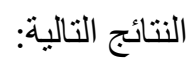

بيانات الانعكاس من اسطح النباتات يمكن استخدامها بنجـاح لتقدير الخو اص الطبيعيـة

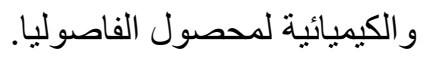

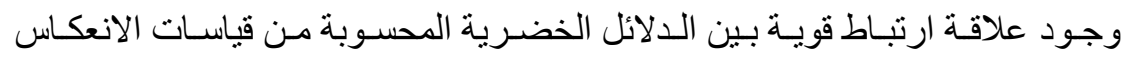

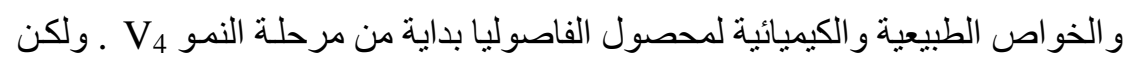

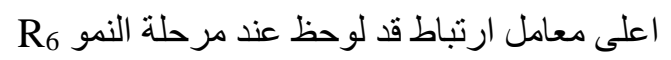
يعتبر (PSNDb) الدليل الخضرى الامثنل في التنبؤ بانتاجيـة محصـول الفاصوليا بمعامل ارتباط 0.595 بينما أظهر الدليل الخضرى (R710/R760 ) حساسية فى تقدير

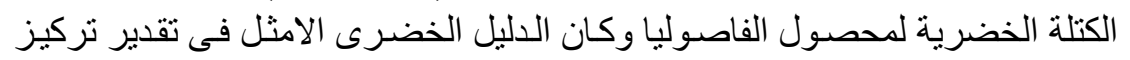
الكلوروفيل هو Crededge و النسبة R750/R700 بمعامل ارتباط بينهما ل

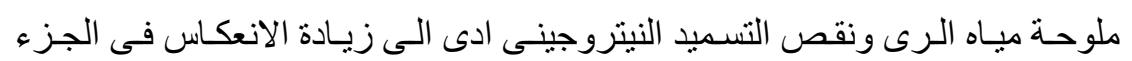

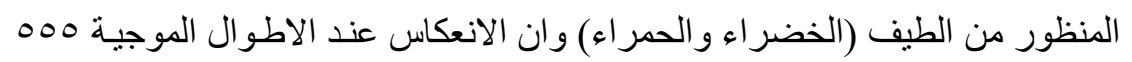
و ومن خلال نتائج هذا البحث نجد أن استخدام صور الاقمار الصناعية عالية الدقة الايضاحية متعددة الاطياف مثل القمر الصناعى هيبريون أو فينوس سيساعد فى استخدام الموارد المتاحة من مياه و اسمدة بكفاءة عالية. 